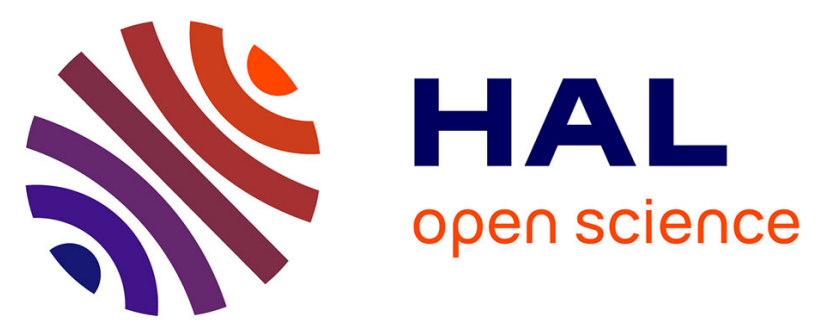

\title{
Nonconventional hydrolytic dehalogenation of 1-chlorobutane by dehydrated bacteria in a continuous solid-gas biofilter
}

Benjamin Erable, Isabelle Goubet, Sylvain Lamare, Amira Seltana, Marie

Dominique Legoy, Thierry Maugard

\section{To cite this version:}

Benjamin Erable, Isabelle Goubet, Sylvain Lamare, Amira Seltana, Marie Dominique Legoy, et al.. Nonconventional hydrolytic dehalogenation of 1-chlorobutane by dehydrated bacteria in a continuous solid-gas biofilter. Biotechnology and Bioengineering, 2005, vol. 91, pp. 304-313. 10.1002/bit.20437 . hal-00786202

\section{HAL Id: hal-00786202 https://hal.science/hal-00786202}

Submitted on 8 Feb 2013

HAL is a multi-disciplinary open access archive for the deposit and dissemination of scientific research documents, whether they are published or not. The documents may come from teaching and research institutions in France or abroad, or from public or private research centers.
L'archive ouverte pluridisciplinaire HAL, est destinée au dépôt et à la diffusion de documents scientifiques de niveau recherche, publiés ou non, émanant des établissements d'enseignement et de recherche français ou étrangers, des laboratoires publics ou privés. 


\title{
Nonconventional Hydrolytic Dehalogenation of 1-Chlorobutane by Dehydrated Bacteria in a Continuous Solid-Gas Biofilter
}

\author{
Benjamin Erable, Isabelle Goubet, Sylvain Lamare, Amira Seltana, \\ Marie Dominique Legoy, Thierry Maugard \\ Laboratoire de Biotechnologies et de Chimie Bio-organique CNRS FRE 2766, \\ Bâtiment Marie Curie, Université de La Rochelle, Avenue Michel Crépeau, \\ 17042 La Rochelle cedex 1, France; telephone: + 335464582 77; \\ fax: + 3354645 8265; e-mail: tmaugard@univ-Ir.fr
}

\begin{abstract}
Rhodococcus erythropolis NCIMB 13064 and Xanthobacter autotrophicus GJ10 are able to catalyze the conversion of halogenated hydrocarbons to their corresponding alcohols. These strains are attractive biocatalysts for gas phase remediation of polluted gaseous effluents because of their complementary specificity for short or medium and for mono-, di-, or trisubstituted halogenated hydrocarbons $\left(\mathrm{C}_{2}-\mathrm{C}_{8}\right.$ for Rhodococcus erythropolis and $\mathrm{C}_{1}-\mathrm{C}_{4}$ for Xanthobacter autotrophicus).

After dehydration, these bacteria can catalyze the hydrolytic dehalogenation of 1-chlorobutane in a nonconventional gas phase system under a controlled water thermodynamic activity $\left(a_{w}\right)$. This process makes it possible to avoid the problems of solubility and bacterial development due to the presence of water in the traditional biofilters.

In the aqueous phase, the dehalogenase activity of Rhodococcus erythropolis is less sensitive to thermal denaturation and the apparent Michaelis-Menten constants at $30^{\circ} \mathrm{C}$ were $0.4 \mathrm{mM}$ and $2.40 \mu \mathrm{mol} \min ^{-1} \mathrm{~g}^{-1}$ for $\mathrm{K}_{\mathrm{m}}$ and $\mathrm{V}_{\text {max }}$, respectively. For Xanthobacter autotrophicus they were $2.8 \mathrm{~m} M$ and $0.35 \mu \mathrm{mol} \min ^{-1} \mathrm{~g}^{-1}$.

In the gas phase, the behavior of dehydrated Xanthobacter autotrophicus cells is different from that observed with Rhododcoccus erythropolis cells. The stability of the dehalogenase activity is markedly lower. It is shown that the $\mathrm{HCl}$ produced during the reaction is responsible for this low stability. Contrary to Rhodococcus erythropolis cells, disruption of cell walls does not increase the stability of the dehalogenase activity.

The activity and stability of Iyophilized Xanthobacter autotrophicus GJ10 cells are dependant on various parameters. Optimal dehalogenase activity was determined for water thermodynamic activity $\left(a_{w}\right)$ of 0.85 . A temperature of $30^{\circ} \mathrm{C}$ offers the best compromise between activity and stability. The $\mathrm{pH}$ control before dehydration plays a role in the ionization state of the dehalogenase in the cells. The apparent Michaelis-Menten constants $\mathrm{K}_{\mathrm{m}}$ and $\mathrm{V}_{\max }$ for the dehydrated Xanthobacter autotrophicus cells were 0.07 (1-chlorobutane thermodynamic activity) and $0.08 \mu \mathrm{mol}$ $\min ^{-1} \mathrm{~g}^{-1}$ of cells, respectively.
\end{abstract}

Correspondence to: Thierry Maugard
A maximal transformation capacity of $1.4 \mathrm{~g}$ of 1-chlorobutane per day was finally obtained using $1 \mathrm{~g}$ of lyophilized Xanthobacter autotrophicus GJ10 cells. (C) 2005 Wiley Periodicals, Inc.

Keywords: bioremediation; haloalkane dehalogenase; Rhodococcus erythropolis NCIMB 13064; solid-gas biofilter; waste air treatment; Xanthobacter autotrophicus GJ10

\section{INTRODUCTION}

Man-made halogenated volatile organic compounds (VOCs) are widely used as solvents and starting materials for the production of paints, agrochemicals, and pharmaceuticals. Due to their persistence and toxicity in the environment and their use in both industry and the home, they may cause considerable environmental pollution and human health problems (Mohn and Tiedje, 1992).

Although there is as yet no precisely international defined legal limit for halogenated VOC emissions, industrialized countries have made air quality a priority. Thus, these compounds are quoted by the U.S. Environmental Protection Agency (EPA) as priority environmental toxic pollutants (U.S. EPA, 1990). In this context, different methods of air treatment based on the physicochemical properties of the pollutant have been developed. One of these methods, biological waste air treatment, is both innovative and inexpensive.

Since they were first used in industry at the end of the 1970s, biological processes in waste air treatment have became increasingly common. The principle of waste air biotranformation is based on the oxidation of organic compounds by microorganisms. This biotechnological approach is an alternative technique that can supply reliable, simple and cheap technologies for air pollutant control (Belkin, 1992; Hardman, 1991).

Several research groups have dealt with some strains capable of hydrolytic dehalogenation of halohaliphatic compounds. The physiology, biochemistry, and genetics of dehalogenating bacteria and substrates specificity of their enzymes are currently being studied (Damborsky et al., 
2001; Hardman, 1991; Janssen, 2004; Janssen et al., 2001, Keuning et al., 1985; Kocabigik, 1989; Nagata et al., 1997).

In particular, a bacterium named Xanthobacter autotrophicus GJ10 is able to use a number of halogenated shortchain hydrocarbons and halogenated carboxylic acids as its sole carbon source for growth (Janssen et al., 1984). This microorganism constitutively produces a haloalkane dehalogenase that converts halogenated alkanes to their corresponding alcohol without the requirement of a coenzyme or oxygen (Shanstra et al., 1996).

The purified haloalkane dehalogenase isolated from Xanthobacter autotrophicus GJ10 catalyzes the hydrolytic dehalogenation of halogenated $\mathrm{C}_{1}$ to $\mathrm{C}_{4}$ alkanes, including chlorinated, brominated, and iodinated compounds (Keuning et al., 1985).

Many studies have focused on solid-liquid-gas biofilters using Xanthobacter autotrophicus GJ10 (Ferreira Jorge and Livingston, 2000; Reij and Hartmans, 1996) but there have been no reports on its use in other waste air biological treatment processes such as in nonconventional media. Recently, we have described the ability of dehydrated Rhodococcus erythropolis NCIMB 13064 cells to transform halogenated alkanes to their corresponding alcohol and $\mathrm{HCl}$ in a solid-gas biofilter (Erable et al., 2004, 2005). The solid-gas biofilter presents numerous advantages over the standard solid-liquid-gas biofilter: (a) there are no problems with the solubility of substrates and/or the products; (b) diffusion in the gaseous phase is more efficient than in solution, making mass transfers more efficient; (c) biomass development is not limiting since the dehydrated cells can't grow; (d) no addition of expensive nutrients is required to maintain cell viability (Lamare and Legoy, 1993).

The strains of Rhodococcus erythropolis NCIMB 13064 and Xanthobacter autotrophicus GJ10 have a different affinity for various substrates. For example, the 1,2dichloroethane, natural substrate of Xanthobacter autotrophicus GJ10, is only slightly transformed by Rhodococcus erythropolis NCIMB 13064 (Schindler et al., 1999). The final goal of this new process is to carry out an association of bacteria able to convert a mixture of pollutants. In this context, the study of Xanthobacter autotrophicus GJ10 in the gas phase is essential to be able to treat dehalogenated short hydrocarbons.

Our purpose in this study was to investigate the ability of Xanthobacter autotrophicus GJ10 to transform 1chlorobutane in a continuous solid-gas biofilter. The behavior of this strain is compared to that obtained with Rhodococcus erythropolis NCIMB 13064.

\section{MATERIALS AND METHODS}

\section{Microorganisms, Culture Conditions, and Chemicals}

The bacterial strain of Xanthobacter autotrophicus GJ10 was a gift from D.B. Janssen's research team, Department of Biochemistry, Groningen Biotechnology Center, Univer- sity of Groningen, The Netherlands. Xanthobacter autotrophicus GJ10 was grown in 1-L aerobic flasks containing $200 \mathrm{~mL}$ of Luria Bertani (LB) medium at $\mathrm{pH} \mathrm{7.0.} \mathrm{The}$ LB medium had the following composition $(\mathrm{g} / \mathrm{L})$ : 10.0 tryptone, 5.0 yeast extract, and $5.0 \mathrm{NaCl}$. The medium was sterilized by autoclaving for $15 \mathrm{~min}$ at $121^{\circ} \mathrm{C}$.

Rhodococcus erythropolis NCIMB 13064 was obtained from the National Collection of Industrial and Marine Bacteria LTD, Aberdeen, Scotland. The organism was grown in 1-L Erlenmeyer flasks sealed with Teflon-lined screw caps; the flasks contained $200 \mathrm{~mL}$ of a medium described by Sorkhoh et al. (1991) at $\mathrm{pH}$ 7.0. After cooling, $100 \mu \mathrm{L}$ of filtered sterilized 1-chlorobutane was added twice as sole carbon source.

Both bacterial cultures were incubated at $30^{\circ} \mathrm{C}$ on an orbital shaker (160 rpm). Cell growth was monitored by measuring the optical density at $690 \mathrm{~nm}$. After $48 \mathrm{~h}$ of growth, cells were harvested by centrifugation at $8000 \mathrm{rpm}$ for 10 minutes.

All substrates were purchased from Sigma Co. (St. Louis, MO) except tryptone and yeast extract, which were obtained from Fluka (USA). Deionized water was obtained via a Milli-Q system (Millipore, France).

\section{Preparation of Cells}

Cells grown for $48 \mathrm{~h}$ were harvested by centrifugation (8000 rpm for $10 \mathrm{~min}$ ), washed with $50 \mathrm{~m} M$ Tris/HCl buffer at $\mathrm{pH} 8.4$ (Xanthobacter autotrophicus) and at $\mathrm{pH} 9.0$ (Rhodococcus erythropolis) and resuspended in $50 \mathrm{mM}$ Tris/ $\mathrm{HCl}$ buffer at the same $\mathrm{pH}$. Part of the cellular suspension was freeze-dried and used for 1-chlorobutane conversion tests in a solid-gas biofilter while the other part was used to measure the haloalkane dehalogenase activities of resting cells in aqueous phase.

\section{Cell Disruption}

The bacteria were disrupted by treatment with lysozyme (obtained from Sigma Chemical Co., St. Louis, MO) or by ultrasonic disruption. $200 \mathrm{mg}$ of lysozyme were added to $600 \mathrm{mg}$ of harvested cells that had been washed and resuspended in $30 \mathrm{~mL}$ of Tris/HCl buffer $(50 \mathrm{mM}$ at $\mathrm{pH} 8.4$ or 9.0 for Xanthobacter autotrophicus GJ10 and Rhodococcus erythropolis NCIMB 13064, respectively). After 15 min incubation at $30^{\circ} \mathrm{C}$, part of the preparation was frozen at $-20^{\circ} \mathrm{C}$ and lyophilized. Alternatively, the cells were subjected to sonication treatment for a time period of between 0 and 10 minutes with a Vibra cell 72434 (Bioblock Scientific) at $50 \mathrm{~W}$ and a frequency of $20 \mathrm{kHz}$.

\section{Enzyme Assay for Dehalogenation in the Aqueous Phase}

The haloalkane dehalogenase activity of resting cells was assayed at $30^{\circ} \mathrm{C}$ in $50 \mathrm{~m} M$ Tris $\mathrm{HCl}$ buffer ( $\mathrm{pH} 8.4$ or 9.0). Tests were performed with $50 \mathrm{~mL}$ of cell suspension (in 
Tris/ $\mathrm{HCl}$ buffer) in $100-\mathrm{mL}$ bottles. One hundred microliters of 1-chlorobutane were added and the reaction was stopped by centrifugation. One milliliter samples of the supernatant were removed and assayed for butan-1-ol levels by gas chromatography analysis using 1-hexanol as an internal standard and the same analytical conditions as for the analysis of the gas phase exiting the reactor.

\section{Enzyme Assay for Dehalogenation in the Solid-Gas Biofilter}

The solid-gas biofilter used in this study was described previously by Lamare and Legoy (1995). It consists of a 9-cm long glass tube in which the lyophilized Xanthobacter autotrophicus GJ10 cells are packed between two layers of glass wool. Substrate feeding was obtained by flowing nitrogen, used as a carrier gas, through the substrate saturation flasks. Substrates were continuously passed through the biofilter and reacted with the lyophilized Xanthobacter autotrophicus GJ10 cells. The gas leaving the biofilter was analyzed by gas chromatography. The acquisition and control of the operating parameters (substrate thermodynamic activity, water thermodynamic activity $\left(\mathrm{a}_{\mathrm{w}}\right)$, temperature, and pressure) were monitored on line as shown in Figure 1.

The thermodynamic activity of each compound $(X)$ in the reactor was calculated as follows:

$$
a_{x}=\frac{P p_{x}}{P p_{x}^{S a t}}
$$

with $P p_{X}$ the partial pressure of compound $\mathrm{X}$ in the gas entering the biofilter and $P p_{X}^{S a t}$ the saturation vapor pressure of pure compound $X$ (atm) at the operating temperature.

The vapor phase leaving the biofilter was sampled using a $250-\mu \mathrm{L}$ loop on a six-way valve (Valco) maintained at $190^{\circ} \mathrm{C}$. Samples were automatically injected into the split injector of a gas chromatograph.

A typical test was carried out at $30^{\circ} \mathrm{C}$, with $100 \mathrm{mg}$ of dehydrated cells. The total flow passing into the biofilter was $500 \mu \mathrm{mol} \mathrm{min}^{-1}$, the 1-chlorobutane thermodynamic activity $\left(\mathrm{a}_{\text {clbut }}\right)$ and the water thermodynamic activity $\left(a_{w}\right)$ were fixed at 0.12 and 0.8 , respectively. With these experimental conditions, less than $5 \%$ of substrate was transformed. These values were expressed in $\mu$ moles of butan-1-ol per minute and per gram of cells.

\section{Chromatographic Analysis}

Analyses were performed on a gas chromatograph (Hewlett Packard model 5890 A), equipped with a flame ionization detector (FID). The column used was an OV 1701 fused silica capillary column $(25 \mathrm{~m} \times 0.25 \mathrm{~mm}$ i.d. $\times 0.25 \mu \mathrm{m}$ film thickness; Chrompack, France). The split ratio was 43.2/2.7. The injector was kept at $200^{\circ} \mathrm{C}$, and the detector was kept at $250^{\circ} \mathrm{C}$. The column temperature was held at $40^{\circ} \mathrm{C}$ for $2.5 \mathrm{~min}$, then programmed to increase at $15^{\circ} \mathrm{C} \min ^{-1}$ to $110^{\circ} \mathrm{C}$ and kept for $1 \mathrm{~min}$ at this temperature. Nitrogen was used as a carrier gas and the flow rate in the column was $2.7 \mathrm{~mL} \mathrm{~min}^{-1}$. Hydrogen and air were supplied to the FID at 38 and $398 \mathrm{~mL} \mathrm{~min}^{-1}$, respectively. Quantitative data were obtained after integration on a HP 3396A integrator.

\section{RESULTS AND DISCUSSION}

\section{Dehalogenase Activities in the Aqueous Phase}

The expression of dehalogenase activity in resting Xanthobacter autotrophicus GJ10 cells in the aqueous phase was

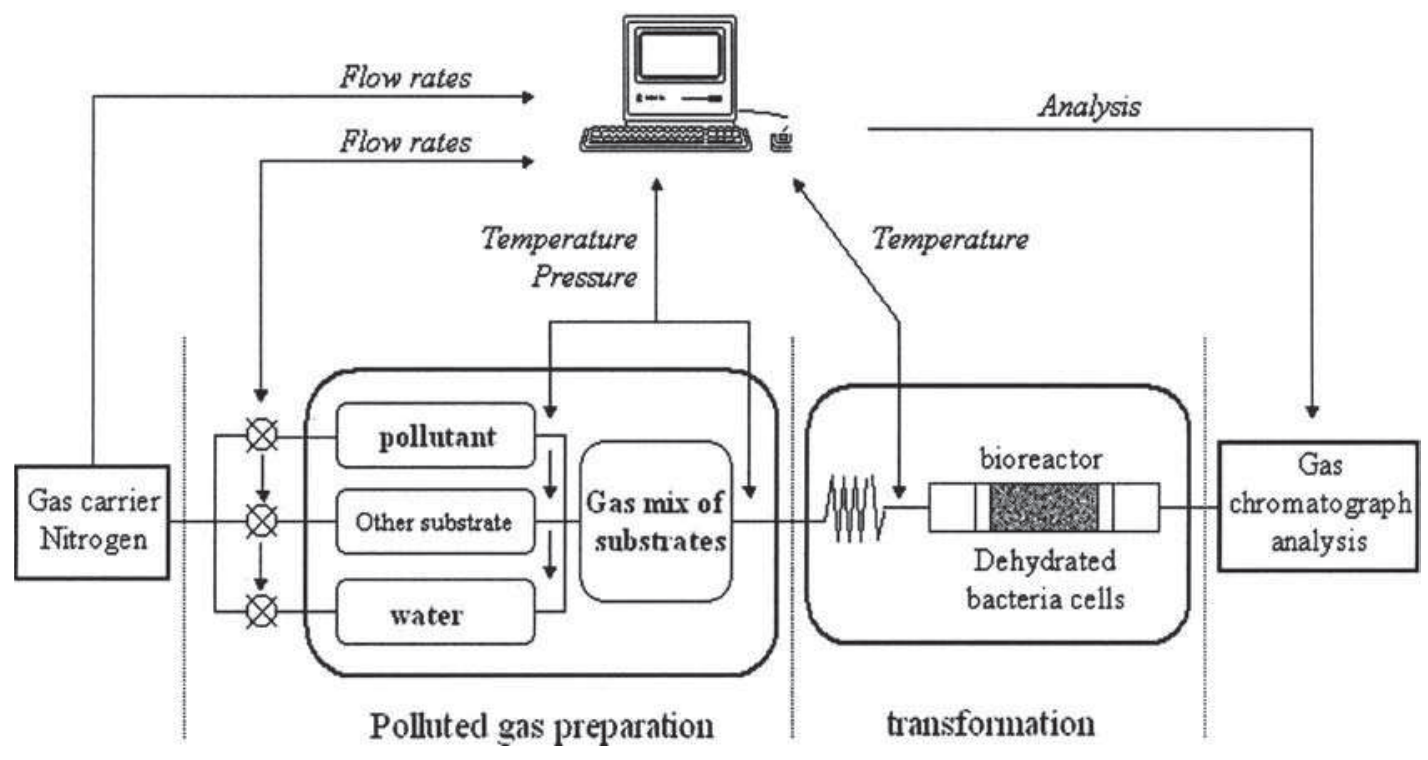

Figure 1. Schematic representation of the nonconventional gas phase biofilter. 
first studied and compared to that of Rhodococcus erythropolis NCIMB 13064. Cells of Xantobacter autotrophicus GJ10 grown on a nutrient media were harvested and used to carry out the irreversible hydrolysis of 1chlorobutane to 1-butanol and $\mathrm{HCl}$. The effect of several parameters such as temperature, buffer $\mathrm{pH}$, buffer concentration, or substrate concentration was investigated. As shown in Table I, the maximum dehalogenase activity of Xanthobacter autotrophicus GJ10 cells was obtained at $\mathrm{pH} 8.4$ and at $30^{\circ} \mathrm{C}$. This dehalogenase activity was very sensitive to temperature and became rapidly inactive at temperatures over $40^{\circ} \mathrm{C}$. Data on the free purified haloalkane dehalogenase of Xanthobacter autotrophicus GJ10 showed that the maximum dehalogenase activity was obtained at $\mathrm{pH} 8.2$ and at a temperature of $37^{\circ} \mathrm{C}$ (Keuning et al., 1985). The optimal Tris/HCl buffer concentration for the dehalogenase activity was found to be $50 \mathrm{mM}$.

The apparent $\mathrm{V}_{\max }$ obtained for 1-chlorobutane conversion with resting Xanthobacter autotrophicus GJ10 cells was $0.35 \mu \mathrm{mol} \mathrm{min}{ }^{-1} \mathrm{~g}^{-1}$ of cells and the apparent $\mathrm{K}_{\mathrm{m}}$ was $2.8 \mathrm{~m} M$ of 1-chlorobutane. The $\mathrm{V}_{\max }$ and $\mathrm{K}_{\mathrm{m}}$ for 1-chlorobutane hydrolysis by the free dehalogenase, as determined by Schindler et al. (1999), were $3.1 \mu \mathrm{mol} \mathrm{min}^{-1}$ $\mathrm{mg}^{-1}$ of protein and $4.1 \mathrm{~m} M$ of 1 -chlorobutane, respectively. Thus, the affinity for 1-chlobutane is weaker for free purified enzyme than with whole cells.

Rhodococcus erythropolis NCIMB 13064 possesses a haloalkane dehalogenase that forms part of the same family of the $\alpha / \beta$ hydrolases as that of the Xanthobacter autotrophicus GJ10 dehalogenase. Moreover, lyophilized cells of this strain have recently been studied in the gas phase for their ability to perform halogenated alkane transformation (Erable et al., 2004, 2005). These two strains are known to convert short haloalkanes such as 1-chlorobutane in the aqueous phase but Rhodococcus erythropolis cells

Table I. Comparison of the optimal parameters for the dehalogenase activities of Xanthobacter autotrophicus GJ10 and Rhodococcus erythropolis NCIMB13064 resting cells in the aqueous phase.

\begin{tabular}{lcc}
\hline & $\begin{array}{c}\text { Xanthobacter } \\
\text { autotrophicus } \\
\text { GJ10 cells }\end{array}$ & $\begin{array}{c}\text { Rhodococcus } \\
\text { erythropolis } \\
\text { NCIMB13064 cells }\end{array}$ \\
\hline $\begin{array}{l}\text { Temperature }\left({ }^{\circ} \mathrm{C}\right) \\
\mathrm{pH}\end{array}$ & 30 & 45 \\
$\begin{array}{c}\text { Tris/HCl buffer } \\
\text { concentration }(\mathrm{mM})\end{array}$ & 8.4 & 9.0 \\
$\begin{array}{c}\text { Apparent } \mathrm{Vmax} \\
\left(\mu \mathrm{mol} \mathrm{min} \mathrm{m}^{-1} \mathrm{~g}^{-1}\right)\end{array}$ & 0.35 & $50-100$ \\
Apparent $\mathrm{Km}(\mathrm{m} M)$ & 2.8 & 2.40 \\
\hline
\end{tabular}

Note: Xanthobacter autotrophicus cells were grown for $48 \mathrm{~h}$ on a LB medium at $30^{\circ} \mathrm{C}$ in $1-\mathrm{L}$ aerobic flask containing $200 \mathrm{~mL}$ of medium. Rhodococcus erythropolis cells were grown for $48 \mathrm{~h}$ on a mineral medium at $30^{\circ} \mathrm{C}$ in $1-\mathrm{L}$ sealed flasks containing $200 \mathrm{~mL}$ of medium to which $100 \mu \mathrm{L}(0.96 \mathrm{mmol})$ were added. The cells were then harvested, washed, and suspended in Tris $\mathrm{HCl}$. Different tests were carried out with $50 \mathrm{~mL}$ of cellular suspension to which $100 \mu \mathrm{L}$ of 1 -chlorobutane was added. Butan1-ol production was measured by GC analysis. has a higher affinity for this substrate $(0.4 \mathrm{mM})$ compared to $2.8 \mathrm{mM}$ for Xanthobacter autotrophicus GJ10 and the apparent $\mathrm{V}_{\max }$ of 1-chlorobutane conversion is 7 times higher than that observed with Xanthobacter autotrophicus

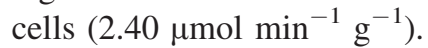

In the aqueous phase, there were some clear differences in terms of 1-chlorobutane dehalogenation between the two strains, Xanthobacter autotrophicus GJ10 and Rhodococcus erythropolis NCIMB 13064. The dehalogenase of Rhodococcus erythropolis NCIMB 13064 offers many advantages such as a higher affinity for 1-chlorobutane, a higher $\mathrm{V}_{\max }$ and greater temperature stability. Usually, the use of a catalyst directly in the gas phase provides greater temperature stability and a higher $\mathrm{V}_{\max }$ compared with the liquid phase. Thus, the question was: How might dehydrated Xanthobacter autotrophicus GJ10 behave in the gas phase?

\section{Continuous 1-Chlorobutane Transformation by Lyophilized Cells of Xanthobacter autotrophicus GJ10 in a Solid-Gas Biofilter: Comparison With Rhodococcus erythropolis NCIMB 13064 Cells}

In a recent article, the ability of dehydrated Rhodococcus erythropolis cells to transform 1-chlorobutane in a solidgas biofilter was reported (Erable et al., 2004, 2005). We proposed to study and compare the same hydrolysis reaction of 1-chlorobutane in butan-1-ol and $\mathrm{HCl}$ with another dehalogenating strain, Xanthobacter autotrophicus GJ10.

In a first test, $200 \mathrm{mg}$ of lyophilized Xanthobacter autotrophicus GJ10 cells were placed in the solid-gas biofilter at $40^{\circ} \mathrm{C}$. The total flow passing into the biofilter was fixed at $500 \mu \mathrm{mol} \mathrm{min}{ }^{-1} . \mathrm{A}_{\text {clbut }}$ and $\mathrm{a}_{\mathrm{w}}$ were fixed at 0.15 and 0.8 , respectively. Butan-1-ol synthesis was monitored by $\mathrm{GC}$ analysis.

Figure 2 clearly shows that Xanthobacter autotrophicus GJ10 cells can transform 1-chlorobutane to butan-1-ol in

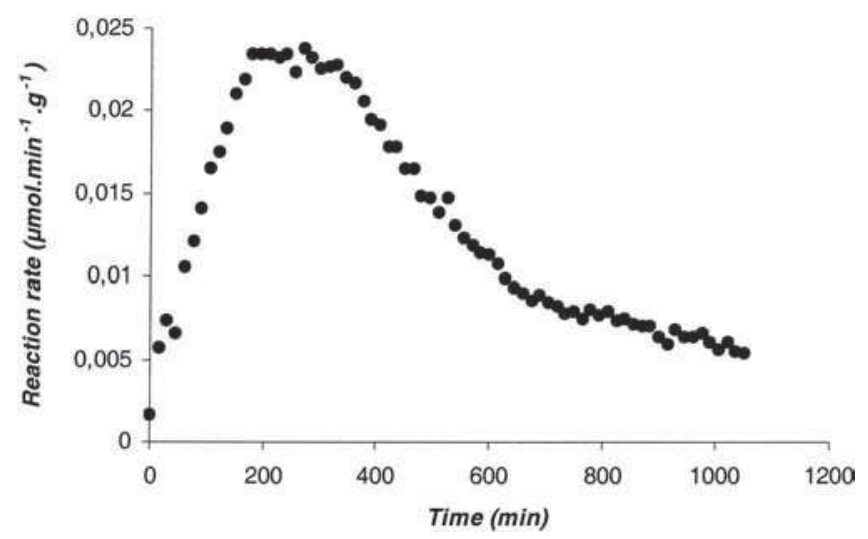

Figure 2. Reaction rate of 1-chlorobutane hydrolysis by dehydrated Xanthobacter autotrophicus GJ10 cells. The reaction was carried out at $40^{\circ} \mathrm{C}$ with $200 \mathrm{mg}$ of dehydrated cells. The total flow passing into the biofilter was $500 \mu \mathrm{mol} \mathrm{min} \mathrm{min}^{-1} \mathrm{a}_{\text {clbut }}$ and $\mathrm{a}_{\mathrm{w}}$ were fixed at 0.15 and 0.8 , respectively. 
the gaseous phase, as was previously demonstrated with dehydrated Rhodococcus erythropolis cells. Moreover, only the dehalogenase seems to be active because the synthesized butan-1-ol wasn't degraded. Other secondary compounds were not detected in the gas phase leaving the reactor. This could be due either to the fact that only small amounts of catalyst were used and that we were not able to detect traces of secondary products, or to the fact that the enzymes involved in the butan-1-ol transformation require cofactors. Janssen et al. $(1984,1989)$ proposed that 1,2dichloroethane is metabolized to 2-chloroethanol by an alcohol dehydrogenase using a PQQ cofactor and Maugard et al. (2001), found that natural cofactor regeneration was not possible in the gas phase with whole cells. Moreover, different tests of cell viability after cell dehydration showed that all the cells used in the gas phase tests were dead.

The initial rate of butan-1-ol formation corresponding to 1-chlorobutane dehalogenation increased to a maximal of $24.10^{-2} \mu \mathrm{mol} \min ^{-1} \mathrm{~g}^{-1}$. The maximal initial rate obtained with these experimental conditions was nearly 100 times lower than that obtained with Rhodococcus erythropolis cells (Erable et al., 2004). This difference in behavior of the two dehydrated strains is in agreement with what has been described in the aqueous phase but the difference is even greater.

The conversion capacity of lyophilized Xanthobacter autotrophicus GJ10 cells was limited because of the loss of dehalogenase activity observed after $300 \mathrm{~min}$ of reaction (Fig. 2). This brutal fall could be due to (a) the effect of water on the catalyst acting as a denaturing agent with temperature; (b) 1-chlorobutane substrate inhibition by cell adsorption and accumulation or a denaturing effect; (c) butan-1-ol product inhibition; (d) $\mathrm{HCl}$ product inhibition by acidification of the dehalogenase catalytic site or by $\mathrm{Cl}^{-}$binding to the catalytic site (Schindler et al., 1999). This loss of activity was already observed using Rhodococcus erythropolis NCIMB 13064 cells.

\section{Inhibition by $\mathrm{HCl}$ Product During Reaction}

In this study, the decrease in dehalogenase activity and the weak stability of the dehydrated cells observed in all tests could be attributed to a deactivation of haloalkane dehalogenase by substrates or products of the 1-chlorobutane hydrolysis reaction. Thermal inactivation can be excluded owing to the fact that the optimal temperature in the aqueous phase was $30^{\circ} \mathrm{C}$ for Xanthobacter autotrophicus GJ10 cells (Table I) and $37^{\circ} \mathrm{C}$ for the purified dehalogenase enzyme (Keuning et al., 1985). Moreover, greater thermal stability of the free enzyme has been demonstrated in gas phase systems (Cameron et al., 2002; Lamare et al., 2001).

To show which of the substrates (water and 1-chlorobutane) or products (butan-1-ol and $\mathrm{HCl}$ ) were responsible for the dehalogenase inhibition, the different compounds were individually passed through a biofilter packed with cells for 400 minutes and a standard test (total flow of $500 \mu \mathrm{mol}$ $\min ^{-1}, \mathrm{a}_{\mathrm{w}}$ of 0.8 and $\mathrm{a}_{\text {clbut }}$ of 0.15 ) was then carried out. The results are presented on Figure 3.

When the catalyst was equilibrated with a water activity fixed at 0.8 for 400 min before being fed with 1-chlorobutane, a higher maximal reaction rate was noticed than when catalyst was directly fed with both water and 1-chlorobutane. These results confirm that catalyst was not denatured by the combined action of water and temperature.

No inhibition of dehalogenase activity was observed after $400 \mathrm{~min}$ of equilibration of the catalyst with 1-chlorobutane or butan-1-ol. These experiments thus clearly show that neither 1-chlorobutane nor butan-1-ol is involved in the inhibition of the catalyst.

On the contrary, an equilibration of the catalyst with $\mathrm{HCl}$ vapor during 200 minutes involves a complete inactivation of the dehalogenase activity.

These data suggest that the dehalogenase inhibition could be explained by $\mathrm{HCl}$ accumulation in the cells during the reaction. $\mathrm{HCl}$ is small hydrophilic molecule and probably diffuses slowly through the cell wall. Its accumulation could have several effects: (a) $\mathrm{HCl}$ accumulation in the microenvironment of the enzyme could cause an acidification of the active site and consequently the ionization state of the amino acids responsible for the activity could change. In a recent article, it was demonstrated that this inhibition could be blocked by the continuous addition of a volatile hydrophobic base (Erable et al., 2005); (b) $\mathrm{HCl}$ is a possible inhibitor of the Xanthobacter autotrophicus GJ10 dehalogenase. It has already been shown that $\mathrm{Cl}^{-}$is an uncompetitive inhibitor of Rhodococcus erythropolis haloalkane dehalogenase (Schindler et al., 1999). The disruption of the bacterial cell wall also appeared to be a solution for avoiding $\mathrm{HCl}$ accumulation. Indeed, cell disruption could allow $\mathrm{HCl}$ diffusion and arrest the decrease in $\mathrm{pH}$ in the environment of the enzyme.

\section{Cells Disruption Effect}

To study the cell disruption effect, tests were carried out at $30^{\circ} \mathrm{C}$ with cells treated with lysozyme or by ultrasonic disruption. The biofilter was packed with $200 \mathrm{mg}$ of treated and dehydrated cells, the total flow was fixed at $500 \mu \mathrm{mol} \mathrm{min}{ }^{-1}, \mathrm{a}_{\mathrm{w}}$ at 0.8 , and $\mathrm{a}_{\text {clbut }}$ at 0.15 .

A negative effect on dehalogenase activity was noticed (Fig. 4). Indeed, 1 minute of ultrasonic disruption treatment led to a decrease of $20 \%$ in the activity and with lysozyme treated cells the decrease was around $40 \%$. The effect of Xanthobacter autotrophicus GJ10 cell disruption didn't correspond to the behavior of dehydrated Rhodococcus erythropolis cells treated with lysozyme as reported by Erable et al. (2004, 2005). The two strains are different in terms of the ultrastructure of their cell wall. Xanthobacter autotrophicus seems to have a Gram-negative type of cell wall while Rhodococcus erythropolis is known to be a Gram-positive bacterium. The disruption of the cell wall of Xanthobacter autotrophicus GJ10 could lead to an enzyme 


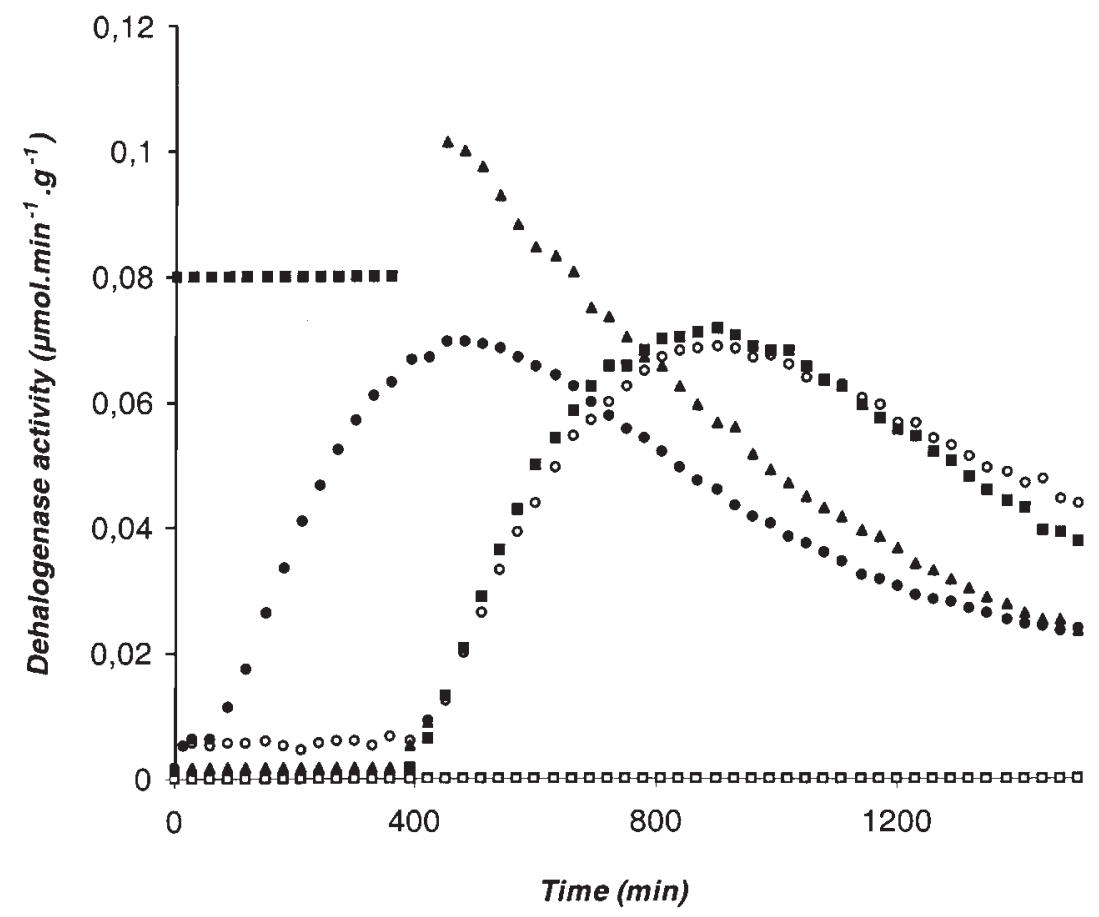

Figure 3. Effect of continuous treatment with substrates or products on the rate of 1-chlorobutane transformation catalyzed by dehydrated Xanthobacter autotrophicus GJ10. Reactions were carried out with $200 \mathrm{mg}$ of lyophilized cells packed into the biofilter at $30^{\circ} \mathrm{C}$ with a total flow fixed at $500 \mu \mathrm{mol}$ $\min ^{-1}$. (•) $\mathrm{a}_{\mathrm{w}}=0.8$ and $\mathrm{a}_{\text {clbut }}=0.15 ;(\boldsymbol{\Delta}) \mathrm{a}_{\mathrm{w}}=0.8$ during 400 min and then $\mathrm{a}_{\mathrm{w}}=0.8$ and $\mathrm{a}_{\text {clbut }}=0.15 ;(\bigcirc) \mathrm{a}_{\text {clbut }}=0.15$ during 400 min and then $\mathrm{a}_{\mathrm{w}}=0.8$ and $\mathrm{a}_{\text {clbut }}=0.15 ;(\mathbf{\square})$ butan-1-ol activity $=0.03$ during 400 min and then $\mathrm{a}_{\mathrm{w}}=0.8$ and $\mathrm{a}_{\text {clbut }}=0.15 ;(\square) \mathrm{HCl}(30 \%)$ activity $=0.6$ during 200 min and then $\mathrm{a}_{\mathrm{w}}=0.8$ and $\mathrm{a}_{\text {clbut }}=0.15$.

destabilization and at the same time to a negative effect on dehalogenase activity. This hypothesis is supported by the data depicted in Figure 5, where the relative dehalogenase activity decreased with the time cells were exposed to ultrasonic disruption. It should be noted that the same effect was obtained in the aqueous phase (data not shown).

Because disruption of cell wall induces a decrease of the dehalogenase activity, further tests in the gas phase were performed with whole dehydrated cells.

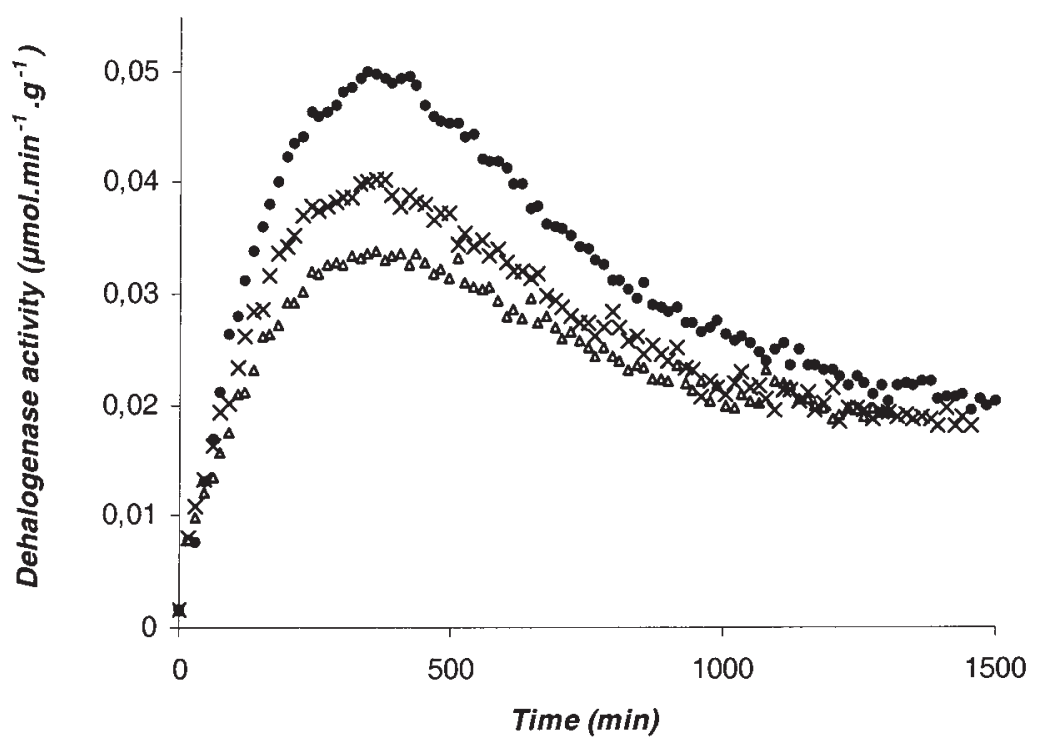

Figure 4. Rate of 1-chlorobutane transformation catalyzed by disrupted and dehydrated Xanthobacter autotrophicus GJ10 cells as a function of reaction time. Cells were disrupted by ultrasound treatment $(\times)$ or using lysozyme $(\Delta)$. The reaction was carried out with $200 \mathrm{mg}$ of lyophilized cells packed into the biofilter at $30^{\circ} \mathrm{C}$ with a total flow fixed at $500 \mu \mathrm{mol} \mathrm{min}^{-1}$. $\mathrm{A}_{\mathrm{w}}$ and $\mathrm{a}_{\mathrm{clbut}}$ were fixed at 0.8 and 0.15 , respectively. Untreated cells were used as witness $(\bullet)$. 


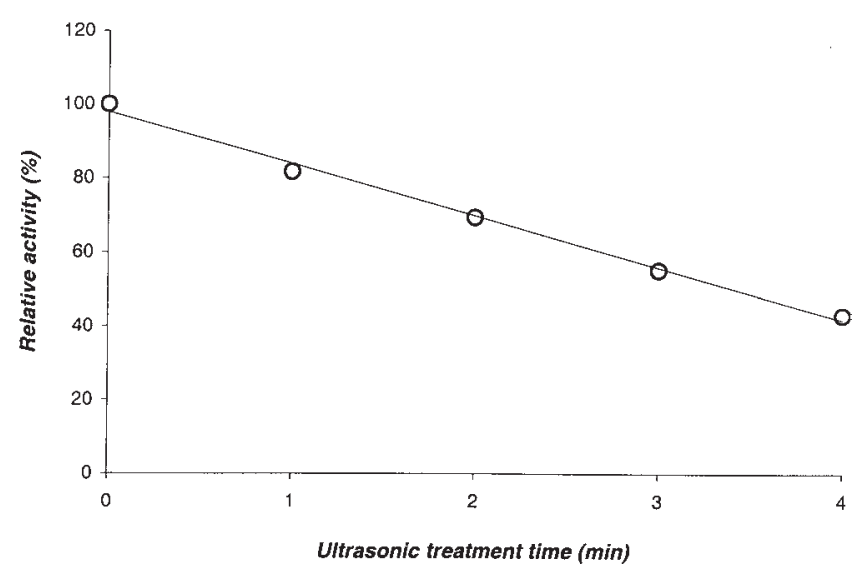

Figure 5. Effect of ultrasound treatment on relative dehalogenase activity of Xanthobacter autotrophicus GJ10. Cells were permeabilized by ultrasound treatment. The reaction was carried out with $200 \mathrm{mg}$ of lyophilized cells packed into the biofilter at $30^{\circ} \mathrm{C}$ with a total flow fixed at $500 \mu \mathrm{mol} \mathrm{min}{ }^{-1} . \mathrm{A}_{\mathrm{w}}$ and $\mathrm{a}_{\text {clbut }}$ were fixed at 0.8 and 0.15 , respectively.

\section{Water Activity $\left(a_{w}\right)$ Effect on Dehalogenase Activity}

The biofilter was packed with $200 \mathrm{mg}$ of lyophilized cells. The total flow passing into the biofilter was $500 \mu \mathrm{mol}$ $\min ^{-1}$ and the $\mathrm{a}_{\text {clbut }}$ was fixed at 0.15 . All reactions were carried out at $30^{\circ} \mathrm{C}$ with different $\mathrm{a}_{\mathrm{w}}$ conditions ( 0.5 to 0.85 ). The results are shown in Figure 6.

The initial rate of butan-1-ol synthesis increased under $\mathrm{a}_{\mathrm{w}}$ conditions of 0.5 to 0.85 . The water and substrate adsorption on dehydrated cells increased in a similar way. The relation between water sorption and dehalogenase activity could be explained by the fact that water is a substrate for the hydrolysis reaction and also probably that water adsorption supported molecular mobility and enzymatic flexibility (Graber et al., 2003). Over the range of tested $\mathrm{a}_{\mathrm{w}}$, optimal dehalogenase activity was obtained for an $\mathrm{a}_{\mathrm{w}}$ of 0.85 .

These results are in agreement with what has already been reported with Rhodococcus erythropolis cells (Erable et al., 2004) and with whole baker's yeast cells for alcohol dehydrogenase activity (Goubet et al., 2002; Maugard et al., 2001).

\section{Temperature Effect}

The effect of temperature on the dehalogenase activity of dehydrated cells in the gaseous phase was tested over a range of temperatures from $30^{\circ} \mathrm{C}$ to $60^{\circ} \mathrm{C}$. The biofilter was packed with $200 \mathrm{mg}$ of lyophilized Xanthobacter autotrophicus GJ10 cells and fed with $500 \mu \mathrm{mol} \mathrm{min}{ }^{-1}$ of gaseous phase; $\mathrm{a}_{\text {clbut }}$ and $\mathrm{a}_{\mathrm{w}}$ were fixed at 0.15 and 0.8 , respectively.

In the gaseous phase, the optimal temperature for Xanthobacter autotrophicus dehalogenase activity was $30^{\circ} \mathrm{C}$ and no activity was observed at temperatures higher than $50^{\circ} \mathrm{C}$. The results obtained with dehydrated Rhodococcus erythropolis cells showed a constant increase of dehalogenase activity with temperatures from $30^{\circ} \mathrm{C}$ to

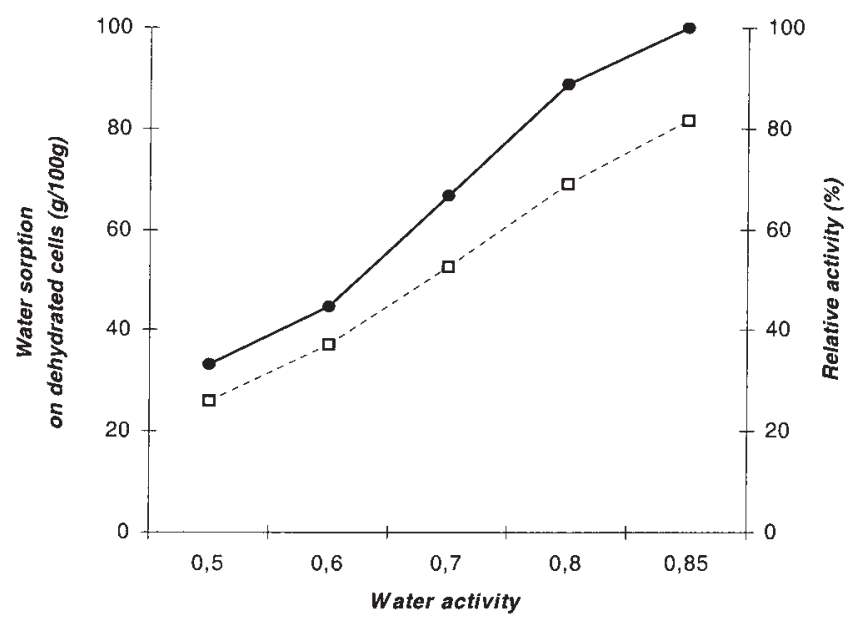

Figure 6. Effect of water activity on relative activity of Xanthobacter autotrophicus GJ10 cells (•) and on water cell adsorption ( $\square$ ). Reactions were carried out at $30^{\circ} \mathrm{C}$ with $200 \mathrm{mg}$ of dehydrated cells. The total flow passing into the biofilter was $500 \mu \mathrm{mol} \mathrm{min}{ }^{-1} ; \mathrm{a}_{\text {clbut }}$ and $\mathrm{a}_{\mathrm{w}}$ were fixed at 0.15 and 0.8 , respectively.

$60^{\circ} \mathrm{C}$ (Erable et al., 2004). However, the results obtained with Xanthobacter autotrophicus GJ10 were different. In fact, Xanthobacter autotrophicus cells are more sensitive to thermal denaturation than Rhodococcus erythropolis cells even in the gas phase.

\section{Effect of Buffer pH Before Dehydration}

The optimal $\mathrm{pH}$ in the aqueous phase for cellular dehalogenase activity was found to be 8.4 , whereas an optimal pH 8.2 was obtained with the purified enzyme (Keuning et al., 1985). In nonconventional media, enzyme activity is often dependent on the ionization state of the enzyme before dehydration ( $\mathrm{pH}$ memory) (Zaks and Klibanov, 1985). Thus, Xanthobacter autotrophicus cells were lyophilized at different $\mathrm{pH}$ from 4.0 to 10.5 and tested in the solid-gas biofilter. The plot obtained for the dehalogenase activity of the dehydrated cells as a function of $\mathrm{pH}$ in the gaseous phase was similar to that obtained in the aqueous phase with an optimal $\mathrm{pH}$ of 8.4 (Fig. 7). Therefore, the $\mathrm{pH}$ memory of dehydrated cells exists in the gas phase too.

\section{1-Chlorobutane Activity Effect}

The effect of $\mathrm{a}_{\text {clbut }}$ on the dehalogenase of dehydrated Xanthobacter autitrophicus GJ10 cells was studied. The biofilter was packed with $200 \mathrm{mg}$ of lyophilized cells and the total flow passing into the biofilter was fixed at $500 \mu \mathrm{mol} \mathrm{min} \mathrm{mith}^{-1}$ with $\mathrm{a}_{\mathrm{w}}$ of 0.8 . Only $\mathrm{a}_{\text {clbut }}$ increased from 0.015 to 0.18 at $30^{\circ} \mathrm{C}$. The results are reported in Figure 8 .

The maximal reaction rate of butan-1-ol synthesis increased with $\mathrm{a}_{\text {clbut }}$. The plot looked like a typical MichaelisMenten enzyme-type and no inhibitory effect was observed 


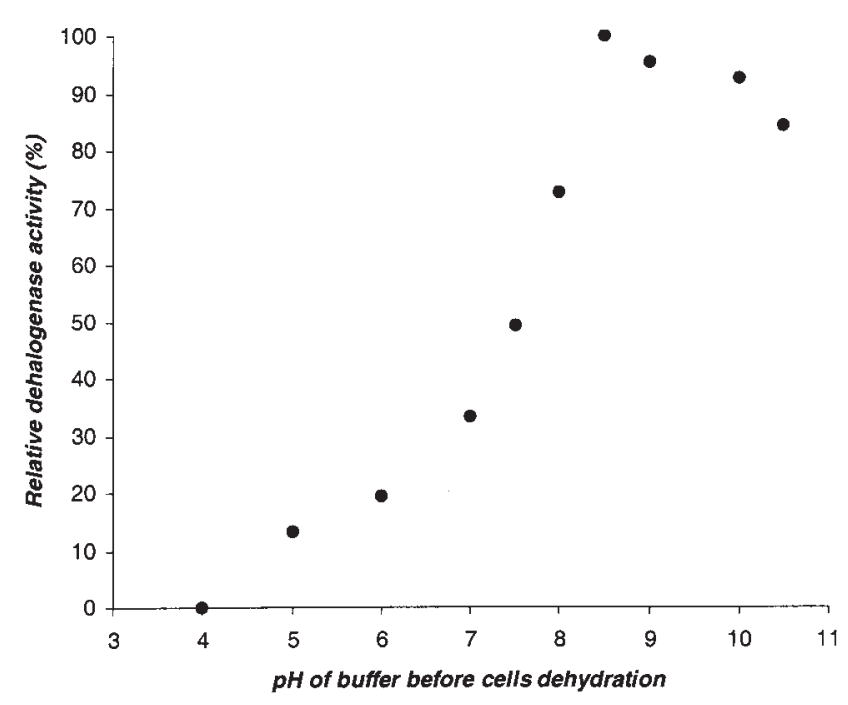

Figure 7. Effect of the $\mathrm{pH}$ of buffer before dehydration of cells on relative dehalogenase activity of Xanthobacter autrophicus GJ10. The reaction was carried out with $200 \mathrm{mg}$ of lyophilized cells packed into the biofilter at $30^{\circ} \mathrm{C}$ with a total flow fixed at $500 \mu \mathrm{mol} \mathrm{min}{ }^{-1} . \mathrm{A}_{\mathrm{w}}$ and $\mathrm{a}_{\text {clbut }}$ were fixed at 0.8 and 0.15 , respectively.

with high $\mathrm{a}_{\text {clbut }}$. Reciprocal initial rates vs. reciprocal $\mathrm{a}_{\text {clbut }}$ were used to determine the apparent Michaelis-Menten constants $\mathrm{V}_{\max }$ and $\mathrm{K}_{\mathrm{m}}$, taking into account the fact that the maximal $\mathrm{a}_{\text {clbut }}$ was 1 . Thus, the apparent $\mathrm{V}_{\max }$ of $8.10^{-2} \mu \mathrm{mol} \mathrm{m^{-1 }} \mathrm{g}^{-1}$ and $\mathrm{K}_{\mathrm{m}}$ of 0.07 (1-chlorobutane thermodynamic activity) were determined at $30^{\circ} \mathrm{C}$.

The apparent Michaelis-Menten constants $\mathrm{V}_{\max }$ and $\mathrm{K}_{\mathrm{m}}$ obtained with dehydrated Rhodococcus erythropolis cells
Table II. Effect of the total flow passing into the biofilter on the 1-chlorobutane transformation rate by dehydrated Xanthobacter autotrophicus GJ10 cells.

\begin{tabular}{|c|c|c|c|}
\hline 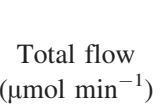 & $\begin{array}{c}\text { 1-chlorobutane } \\
\text { flow }\left(\mu \mathrm{mol} \mathrm{min}^{-1}\right)\end{array}$ & $\begin{array}{l}\text { Residence time } \\
\text { in the reactor }(\mathrm{s})\end{array}$ & $\begin{array}{l}\text { 1-chlorobutane } \\
\text { transformation rate } \\
\left(\mathrm{nmol} \min ^{-1} \mathrm{~g}^{-1}\right)\end{array}$ \\
\hline 180 & 5.4 & 15.3 & 88 \\
\hline 280 & 7.4 & 9.8 & 83 \\
\hline 500 & 14.2 & 5.5 & 73 \\
\hline 780 & 22.7 & 3.5 & 65 \\
\hline
\end{tabular}

Note: Reactions were carried out at $30^{\circ} \mathrm{C}$ with $200 \mathrm{mg}$ of dehydrated cells. The total flow passing into the biofilter was variable; $a_{\text {clbut }}$ and $a_{w}$ were fixed at 0.15 and 0.8 , respectively.

were previously described by Erable et al. (2005). They reported an apparent $\mathrm{V}_{\max }$ of $3.22 \mu \mathrm{mol} \min ^{-1} \mathrm{~g}^{-1}$ and an apparent $\mathrm{K}_{\mathrm{m}}$ of 0.011 (1-chlorobutane thermodynamic activity) at $40^{\circ} \mathrm{C}$. Dehydrated Rhodococcus erythropolis cells had a higher affinity for the 1-chlorobutane substrate in the gaseous phase; this was also reported by the data obtained in the aqueous phase (Table I). Moreover, the rate of catalysis of 1-chlorobutane transformation was 40 times lower with dehydrated Xanthobacter autotrophicus cells, whereas this ratio was only 7 in the aqueous phase.

\section{Effect of the Total Flow Passing Into the Biofilter}

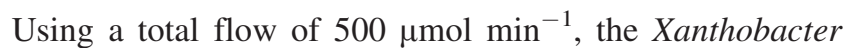
autotrophicus GJ10 dehalogenase activity was relatively weak. However, in a continuous process the reduction of

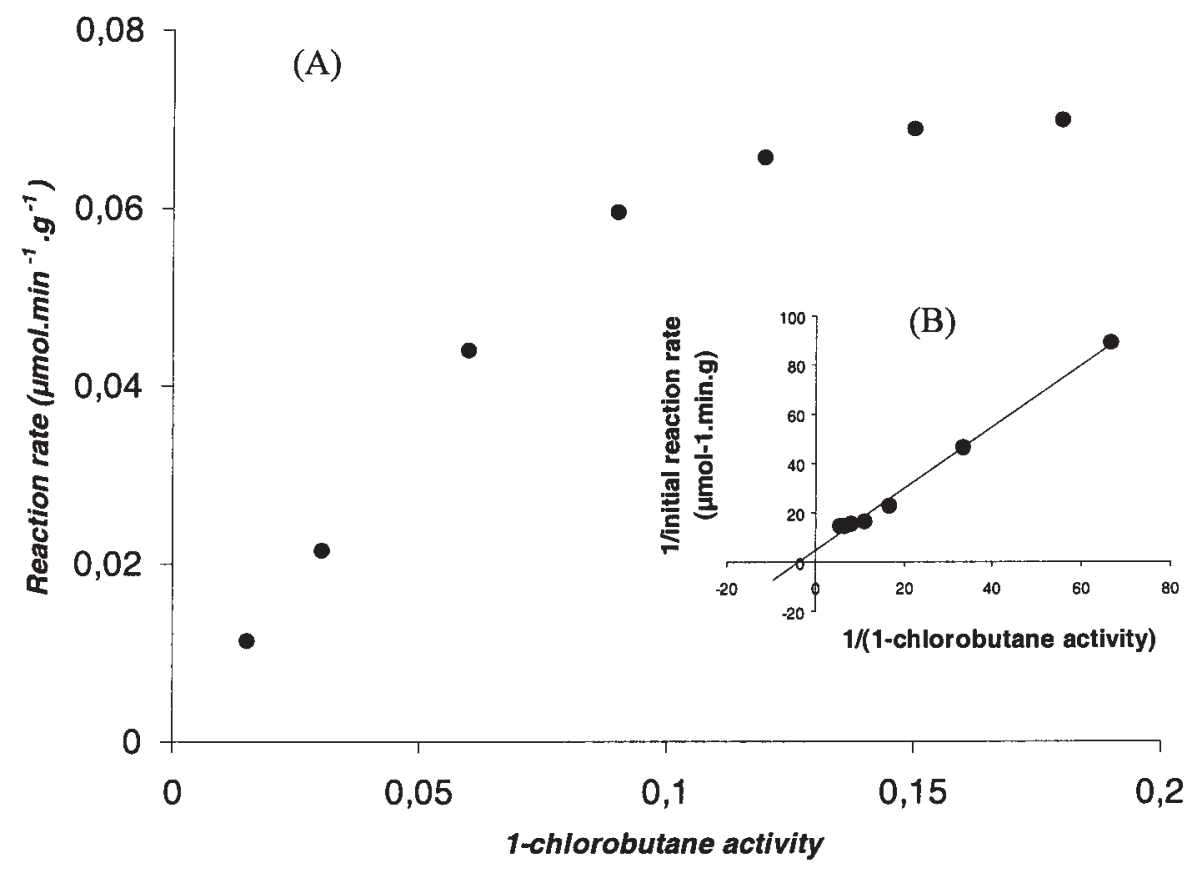

Figure 8. Reaction rate of the 1-chlorobutane transformation as a function of $\mathrm{a}_{\text {clbut }}(\mathrm{A})$ and reciprocal initial reaction rate of the hydrolysis of 1-chlorobutane vs. reciprocal $\mathrm{a}_{\text {clbut }}$ (B). Reactions were carried out at $30^{\circ} \mathrm{C}$ with $200 \mathrm{mg}$ of dehydrated cells. The total flow passing into the biofilter was $500 \mu \mathrm{mol} \min ^{-1}$ and $\mathrm{a}_{\mathrm{w}}$ was fixed at 0.8 . 
the total flow usually increases substrate conversion. It was decided to increase substrate residence time in the biofilter in an attempt to increase 1-chlorobutane degradation. Thus, the reaction rate was measured at different total flow while $\mathrm{a}_{\mathrm{w}}$ and $\mathrm{a}_{\text {clbut }}$ were maintained constant (0.8 and 0.15 , respectively).

Total flows tested for the 1-chlorobutane conversion varied from 180 to $780 \mu \mathrm{mol} \mathrm{min}^{-1}$. The contact time between catalyst and substrate was 4.2-fold longer when the total flow was fixed at $180 \mu \mathrm{mol} \mathrm{m^{-1 }}$ (Table II). In fact, the residence time of the substrate was $15.3 \mathrm{~s}$ at $180 \mu \mathrm{mol} \mathrm{min}{ }^{-1}$ and only $3.5 \mathrm{~s}$ at $780 \mu \mathrm{mol} \mathrm{min} \mathrm{m}^{-1}$. At the same time, the observed 1-chlorobutane transformation rate increase by $35 \%\left(65 \mathrm{nmol} \mathrm{min} \mathrm{m}^{-1} \mathrm{~g}^{-1}\right.$ to $88 \mathrm{nmol} \mathrm{min}$ $\mathrm{g}^{-1}$ ) when the total flow decreased from 780 to $180 \mu \mathrm{mol}$ $\min ^{-1}$. These results clearly show that total flow passing into the gas phase biofilter do not influence too much the 1-chlorobutane conversion rate.

\section{Effect of the Amount of Dehydrated Cells Packed Into the Biofilter}

In Figure 2, the initial rate of butan-1-ol synthesis increased to a maximal value after 300 minutes of reaction and in a second phase butan-1-ol production decreased to almost zero. Using these experimental conditions (200 mg of dehydrated Xanthobacter autotrophicus GJ10 cells, total flow of $500 \mu \mathrm{mol} \mathrm{min}{ }^{-1}, \mathrm{a}_{\mathrm{w}}$ of 0.8 and $\mathrm{a}_{\text {clbut }}$ of 0.15 at $30^{\circ} \mathrm{C}$ ), $200 \mathrm{mg}$ of catalyst cannot last more than 1500 hours.

Consequently, the effect of dehydrated cells packed into the biofilter on 1-chlorobutane transformation capacity was studied. The experimental conditions were fixed at $500 \mu \mathrm{mol} \mathrm{min} \mathrm{m}^{-1}$ at $30^{\circ} \mathrm{C}$ with an $\mathrm{a}_{\mathrm{w}}$ and $\mathrm{a}_{\text {clbut }}$ of 0.8 and 0.15 , respectively. Only the quantity of cells packed into

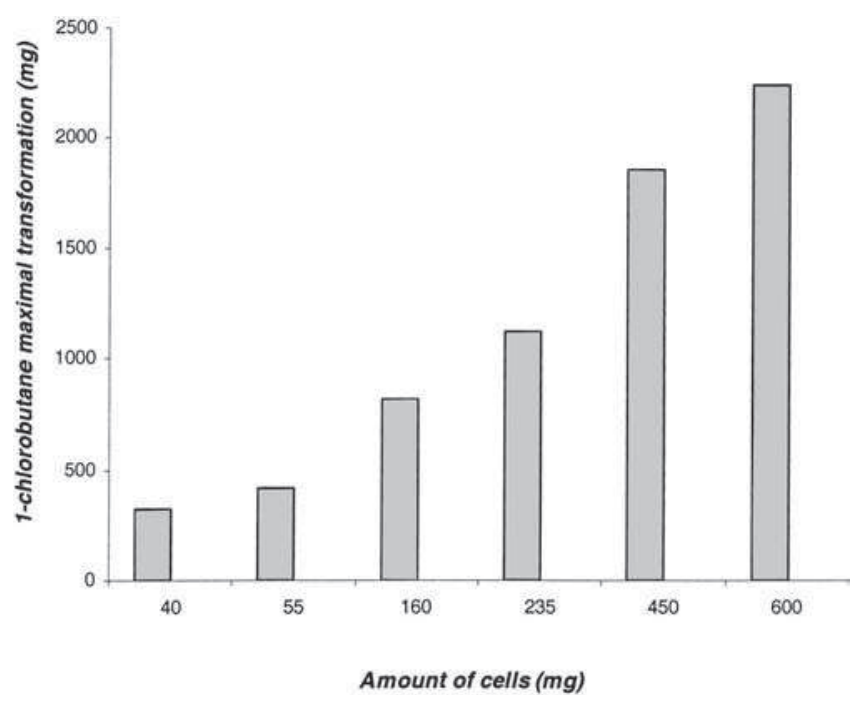

Figure 9. Maximal 1-chlorobutane transformation capacity of dehydrated Xanthobacter autotrophicus GJ10 cells as a function of the quantity of cells. The total flow passing into the biofilter was $500 \mu \mathrm{mol} \mathrm{min}{ }^{-1}$; $\mathrm{a}_{\text {clbut }}$ and $\mathrm{a}_{\mathrm{w}}$ were fixed at 0.15 and 0.8 , respectively. the biofilter varied from 40 to $600 \mathrm{mg}$. The results show that the 1-chlorobutane transformation capacity of dehydrated Xanthobacter autotrophicus GJ10 cells is proportional to the amount of catalyst packed into the solid-gas biofilter (Fig. 9). We have estimated that $1 \mathrm{~g}$ of lyophilized cells can transform $1.4 \mathrm{~g}$ of 1-chlorubutane in 24 hours.

\section{CONCLUSION}

The ability of dehydrated Xanthobacter autotrophicus GJ10 cells to transform 1-chlorobutane in a solid-gas biofilter was initially highlighted. The behavior of this strain in the gas phase was different to that previously observed with Rhododcoccus erythropolis NCIMB 13064. The low stability of continuous 1-chlorobutane dehalogenation was clearly due to the inhibition by $\mathrm{HCl}$ produced during the reaction and cells disruption did not prevent the accumulation of this product. The study of several important parameters in solid-gas biocatalysis (temperature, water thermodynamic activity, substrates thermodynamic activity, $\mathrm{pH}$ memory) made it possible to increase maximal the dehalogenase activity of whole cells.

Finally, while modulating the balance between the amount of cells packed into the biofilter and the total flow, it was estimated that $1 \mathrm{~g}$ of dehydrated Xanthobacter autotrophicus GJ10 cells could dehalogenate $1.4 \mathrm{~g}$ of 1-chlorobutane per day.

Our research is now concentrated on the problem of the stability of cell dehalogenase activity. A special effort is being undertaken to understand and to avoid the $\mathrm{HCl}$ accumulation in the cell.

We thank D.B. Janssen (Department of Biochemistry, Groningen Biotechnology Center, University of Groningen) for providing the Xanthobacter autotrophicus GJ10 strain.

\section{References}

Belkin S. 1992. Biodegradation of haloalkanes. Biodegradation 3:299-313. Cameron PA, Davidson BH, Frymier PD, Barton JW. 2002. Direct transesterification of gases by "dry" immobilised lipase. Biotechnol Bioeng 78:251-256.

Damborsky J, Ronije E, Jesenka A, Nagata Y, Klopman G, Peijnenburg WJGM. 2001. Structure-specificity relationships for haloalkane dehalogenases. Environ Tox Chem 20:2681-2689.

Erable B, Goubet I, Maugard T, Lamare S, Legoy MD. 2004. Haloalkane hydrolysis by Rhodococcus erythropolis cells: Comparison of conventional aqueous phase dehalogenation and nonconventional gas phase dehalogenation. Biotechnol Bioeng 86:47-54.

Erable B, Maugard T, Goubet I, Lamare S, Legoy MD. 2005. Biotransformation of halogenated compounds by lyophilized cells of Rhodococcus erythropolis in a continuous solid-gas biofilter. Proc Biochem 40:45-51.

Ferreira Jorge RB, Livingston AG. 2000. Microbial dynamics in a continuous stirred tank bioreactor exposed to an alternating sequence of organic compounds. Biotechnol Bioeng 69:409-417.

Goubet I, Maugard T, Lamare S, Legoy MD. 2002. Role of water activity and temperature on activity and stability of dried whole cells of Saccharomyces cerevisiae in a continuous solid-gas reactor. Enzyme Microbiol Technol 31:425-430. 
Graber M, Bousquet-Dubouch MP, Sousa N, Lamare S, Legoy MD. 2003. Water plays a different role on activation thermodynamic parameters of alcoholisis reaction catalyzed by lipase in gaseous or organic media. Biochem Biophys Acta 1645:56-62.

Hardman DJ. 1991. Biotransformation of halogenated compounds. Crit Rev Biotech 1:1-40.

Janssen DB, Scheper A, Dijkhuizen L, Witholt B. 1985. Degradation of halogenated aliphatic compounds by Xanthobacter autotrophicus GJ10. Appl Environ Microbiol 57:673-677.

Janssen DB, Pries F, Van Der Ploeg J, Kazemier B, Terpstra P, Witholt B. 1989. Cloning of 1,2-dichloroethane degradation genes of Xanthobacter autotrophicus GJ10 and expression and sequencing of the dhlA gene. J Bacteriol 171:6791-6799.

Janssen DB, Oppentocht JE, Poelarends GJ. 2001. Microbial dehalogenation. Curr Opin Biotechnol 12(3):254-258.

Janssen DB. 2004. Evolving haloalkane dehalogenase. Curr Opin Chem Biol 8(2):150-159.

Keuning S, Janssen DB, Witholt B. 1985. Purification and characterization of a hydrolytic haloalkane dehalogenase from Xanthobacter autotrophicus GJ10. J Bact 163:635-639.

Kocabigik S. 1989. A thermo-stable dehalogenase in the extracts from Pseudomonas sp. Strain 19S. Biotechnol Lett 11:397-400.

Lamare S, Legoy MD. 1993. Biocatalyse in the gas phase. Trends Biotechnol 11:413-418.

Lamare S, Legoy MD. 1995. Solid/gas biocatalysis how to fully define the system? Biotechnol Tech 9:127-132.

Lamare S, Caillaud B, Roule K, Goubet I, Legoy MD. 2001. Production of natural esters at the pre-industrial scale by solid/gas biocatalysis. Biocat Biotrans 19:361-377.

Maugard T, Lamare S, Legoy MD. 2001. Gas phase biotransformation reaction catalysed by baker's yeast. Biotechnol Bioeng 73:164-168.

Mohn WW, Tiedje JM. 1992. Microbial reductive dehalogenation. Microbiol Revs 56:482-507.

Nagata Y, Miyauchi K, Damborsky D, Manova K, Ansorgova A, Tagagi M. 1997. Purification and characterization of a haloalkane dehalogenase of a new substrate class from a hexachlorocyclohexane-degrading bacterium, Sphingomonas paucimobilis UT26. Appl Environ Microbiol 63:3707-3710.

Reij MW, Hartmans S. 1996. Propene removal from synthetic waste gas using a hollow fibre membrane bioreactor. Appl Microbiol Biotechnol 45(6):730-736.

Schindler JF, Naranjo PA, Honaberger DA, Chang C, Brainard JR, Vanderberg LA, Unkefer CJ. 1999. Haloalkane dehalogenases: Steadystate kinetics and halide inhibition. Biochemistry 38:5772-5778.

Shanstra JP, Kingma J, Janssen DB. 1996. Specificity and kinetics of haloalkane dehalogenase. J Biol Chem 271(25):14747-14753.

Sorkhoh NA, Ghannoum MA, Ibrahim AS, Stretton RJ, Radwan SS. 1991. Growth of Candida albicans in the presence of hydrocarbons: a correlation between sterol concentration and hydrocarbon uptake. Appl Microbiol Biotechnol 34:509-512.

U.S. Environmental Protection Agency. 1990. Clean Air Act Amendments (CAAA). Available from: http://www.epa.gov/air/oaq_caa.html.

Zaks A, Klibanov AM. 1985. Enzyme-catalysed processes in organic solvents. Proc Natl Acad Sci USA 82:3192-3196. 